\title{
Sebaran Thermal Front Musiman di Wilayah Perairan Selat Madura Menggunakan Single Image Edge Detection
}

\author{
Trinugroho Trinugroho, Alfi Satriadi, Muslim Muslim \\ Departemen Oseanografi, Fakultas Perikanan dan Ilmu Kelautan, Universitas Diponegoro \\ Jl. Prof.H.Soedarto S.H, Tembalang,Semarang, Jawa Tengah 50275 Indonesia \\ *Corresponding author, e-mail : tnugroho9.96@gmail.com
}

\begin{abstract}
ABSTRAK:Thermal front didefinisikan sebagai pertemuan antara dua masa air dengan karakteristik suhu yang berbeda sehingga membentuk gradien suhu. Thermal front merupakan salah satu proses oseanografi penting yang dapat mempengaruhi kondisi fisik, kimia, maupun biologi di laut. Tujuan dari penelitian ini adalah untuk mengetahui sebaran thermal front musiman di perairan Selat Madura, Jawa Timur. Deteksi thermal front dilakukan pada lapisan permukaan laut dengan menggunakan citra AquaMODIS untuk suhu permukaan laut. Citra AquaMODIS yang digunakan memiliki resolusi spasial sebesar $1 \mathrm{~km} \times 1 \mathrm{~km}$ dan resolusi temporal selama satu hari. Metode yang digunakan untuk mendeteksi fenomena ini adalah metode Single Image Edge Detection (SIED) yang diperkenalkan oleh Cayula dan Cornilon pada tahun 1992. Metode ini menggunakan prinsip deteksi tepi piksel yang mempertimbangkan nilai gradien suhu dan pola arah dari piksel yang memiliki gradien suhu. Hasil yang diperoleh berupa sebaran spasial dan temporal fenomena thermal front di perairan Selat Madura. Sebaran temporal berdasarkan komposit harian dalam satu musim selama empat tahun dari tahun 2012 - 2016. Rata - rata kejadian thermal front tiap musim sebanyak 446 kali pada musim barat, 1893 kali pada musim peralihan I, 1038 kali pada musim timur, dan 2375 kali pada musim peralihan II. Penyebab utama kejadian front di perairan Selat Madura adalah akibat adanya arus eddy dan masukan masa air laut dari wilayah timur Selat Madura.
\end{abstract}

Kata Kunci:Thermal Front, Selat Madura, Single Image Edge Detection

\section{Seasonal Thermal Front Distribution Along The Madura Strait Based on Single Image Edge Detection}

\begin{abstract}
Thermal front defined as an ecounter of two water masses which has different temperature (thermal) characteristics and create a thermal gradient. Thermal front is one of the most important oceanographic proceses that can make a significant impact to physical, chemical, and biological process in the ocean. The aim of this research is to understand seasonal thermal front distribution in Madura Strait, East Java. Thermal front was detected in the surface layer of water, using AquaMODIS for Sea Surface Temperature (SST). AquaMODIS image which used in this research has $1 \mathrm{~km} \times 1 \mathrm{~km}$ spatial resolution and one day (24 hours) temporal resolution. Front detection in this research is using Single Image Edge Detection by Cayula Cornilon (1992). This method is using edge detection of pixel, considering the value of thermal gradient and pattern of the pixel edge. The result of this research is spatial and temporal distribution of thermal front in Madura Strait. Temporal distribution are based on composite result of daily front detection in seasonal range for four years from 2012-2016. Seasonal average of front occurence is 446 times in western season, 1893 times in Transition I, 1038 times in eastern season and 2375 times in Transition II. The main cause of front in Madura strait is eddy current and water masses ecounter from eastern area of Madura.
\end{abstract}

Keywords: Thermal Front, Madura Strait, Single Image Edge Detection

\section{PENDAHULUAN}

Suhu merupakan salah satu parameter oseanografi penting di laut yang dapat berubah-ubah sehingga pengukuran suhu menjadi dasar bagi para peneliti di bidang oseanografi untuk 
mendiskripsikan karakteristik suatu massa air sebagai indikator berbagai fenomena yang ada di lautan (Akhbar et al.,2018)

Kemajuan metode penginderaan jauh dalam bidang oseanografi seperti deteksi Suhu Permukaan Laut (SPL) dapat digunakan untuk mendeteksi fenomena oseanografi yang berkaitan dengan pertemuan massa air, tidal mixing, upwelling dan proses oseanografi lainnya yang dapat menyebabkan terjadinya gradien suhu sehingga dapat diidentifikasikan sebagai thermal front (Belkin dan O'Reilly, 2009). Penelitian thermal front dapat dintegrasikan dengan faktor-faktor oseanografi menggunakan system informasi geografis (Valavanis et al., 2005)

Front dapat didefinisikan sebagai pertemuan antara dua massa air yang mempunyai karakteristik suhu yang berbeda. Fenomena ini merupakan salah satu proses dalam oseanografi yang berpengaruh terhadap kondisi fisis dan biologis di perairan. Fenomena front yang terbentuk karena gradien suhu, disebut dengan thermalfront (Hanintyo et al., 2015). Secara umum thermal front dapat ditemukan di perairan pesisir. Hal ini dikarenakan hempasan massa air dari daratan mempunyai suhu berbeda dengan suhu air laut, sehingga terbentuklah thermal front (Mustasim et al., 2015)

Fenomena thermal front menjadi topik yang sangat menarik, mengingat fenomena ini cukup sering terjadi di Indonesia, meskipun tidak terjadi sepanjang waktu, mulai dari periode harian, mingguan, bulanan hingga tahunan. Thermal font dapat diindikasikan sebagai wilayah potensial penangkapan ikan (Nammalwar et al., 2013)Fenomena ini dijadikan sebagai salah satu acuan untuk penentuan Zona Potensi Penangkapan Ikan (ZPPI) yang dilakukan oleh beberapa lembaga negara seperti Badan Pusat Observasi Laut (BPOL), Kementerian Kelautan dan Perikanan dan Pusat Pemanfaatan Penginderaan Jauh (Pusfatja), Lembaga Penerbangan dan Antariksa Nasional (Arief, 2004).

Analisis suhu permukaan laut secara spasial di perairan Indonesia dan secara temporal belum banyak dilakukan (Syaifullah M.D.,2015). Selat Madura merupakan perairan dangkal dan semi tertutup yang memisahkan dua pulau, yaitu Pulau Jawa dan Pulau Madura. Perairan ini berbatasan dengan Laut Bali, Selat Bali, dan Laut Jawa sehingga kondisi fisik dan biologi perairannya sangat dipengaruhi oleh ketiga perairan tersebut Perairan ini memiliki rentang perbedaan suhu horizontal maupun vertikal yang tidak begitu besar, berkisar antara $26,5-30{ }^{\circ} \mathrm{C}$ (Hasyim, 2014).

\section{MATERI DAN METODE}

Materi yang digunakan dalam penelitian ini adalah data yang diperoleh dari berbagai sumber, diantaranya: Peta Rupabumi Indonesia tahun 2011 skala 1:25.000 terbitan Badan Informasi Geospasial yang dapat diakses melalui https://tanahair.indonesia.go.id/; Citra satelit AquaMODIS Level 2 tahun 2012-2016 dengan resolusi spasial $1 \mathrm{~km} \times 1 \mathrm{~km}$ dan resolusi temporal selama satu hari, yang dapat diakses melalui https://oceancolor.gsfc.nasa.gov/; Model Arus HYCOM (Hybrid Coordinate Ocean Model) tahun 2012-2016 dengan ukuran grid $1 / 12^{\circ}(9 \mathrm{~km} \times 9$ $\mathrm{km}$ ) yang dapat diakses melalui https://hycom.org/

Metode penelitian yang digunakan dalam penelitian ini adalah metode penelitian kuantitatif. Menurut Hanintyo et al., (2015) pengolahan citra MODIS untuk deteksi thermal front menggunakan cloud masking dan reproyeksi citra dan cropping. Citra satelit MODIS Level 2 yang diunduh pertama-tama diolah dengan menggunakan software SeaDas untuk menghilangkan tutupan awan dan nilai nilai yang diragukan. Proses ini dilakukan dengan memasukkan persamaan logika matematis untuk menghilangkan nilai $\mathrm{NaN}$ atau piksel dengan nilai kosong pada citra. Reproyeksi digunakan untuk mengubah sistem koordinat yang ada pada citra satelit. Cropping dilakukan agar citra yang akan diolah lebih terfokus dan seragam. Proses Cropping dilakukan dengan memotong citra yang telah di reproyeksi berdasarkan batas batas dari koordinat geografis.

Metode deteksi front dengan metode SIED yang diperkenalkan oleh Cayula dan Cornillon pada tahun 1992 yang saat ini algoritma tersebut dimasukkan kedalam ArcGIS Tools MGET (Marine Geospatial Ecology Tools) yang dikembangkan oleh tim dari Duke Marine Geospatial Ecology Lab, Duke University dan disebarkan secara gratis. Basis pemograman yang digunakan pada tools ini adalah bahasa pemograman phyton, atau bahasa pemograman yang sama dengan yang digunakan oleh software ArcGIS. 
Model Arus dibuat dengan mengambil data hasil pemodelan dari HYCOM. Data model arus yang disediakan dari HYCOM berupa data model arus yang ada di berbagai lapisan air, mulai dari kedalaman 0 meter hingga kedalaman 5500 meter. Data model arus yang digunakan adalah data arus harian pada kedalaman 0 meter (lapisan permukaan). Data model arus yang telah diunduh berupa Network Common Data Form (NetCDF) yang kemudian diolah dengan menggunakan software SeaDAS untuk mendapatkan nilai matriks berupa garis lintang, garis bujur, arah arus dalam sumbu $x(u)$ dan arah arus dalam sumbu y (v). Matriks yang dihasilkan kemudian dikonversikan menjadi titik titik yang memiliki nilai kecepatan dan arah arus di dalam software ArcGIS. Untuk mengetahui bagaimana front terbentuk secara harian dilakukan dengan menggabungkan data arus harian HYCOM (berupa kecepatan dan arah arus) dengan hasil deteksi thermal front secara harian. Data model yang digunakan disesuaikan dengan hasil deteksi front yang terdeteksi, dengan mempertimbangkan musim.

\section{HASIL DAN PEMBAHASAN}

Gradien suhu permukaan laut ditunjukkan dalam peta grafik pada Gambar 1. Peta di bagian atas menunjukkan citra suhu permukaan laut, pada wilayah yang terjadi front (ditunjukkan oleh garis biru). Gradien suhu yang terbentuk pada area yang terjadi front dilihat dengan membuat sayatan melintang antara piksel A dan B kemudian hasilnya disajikan pada grafik yang terletak di bagian bawah peta. Gradien yang terbentuk menunjukkan perbedaan nilai suhu antar piksel sebesar $0,5^{\circ} \mathrm{C} /$ piksel.

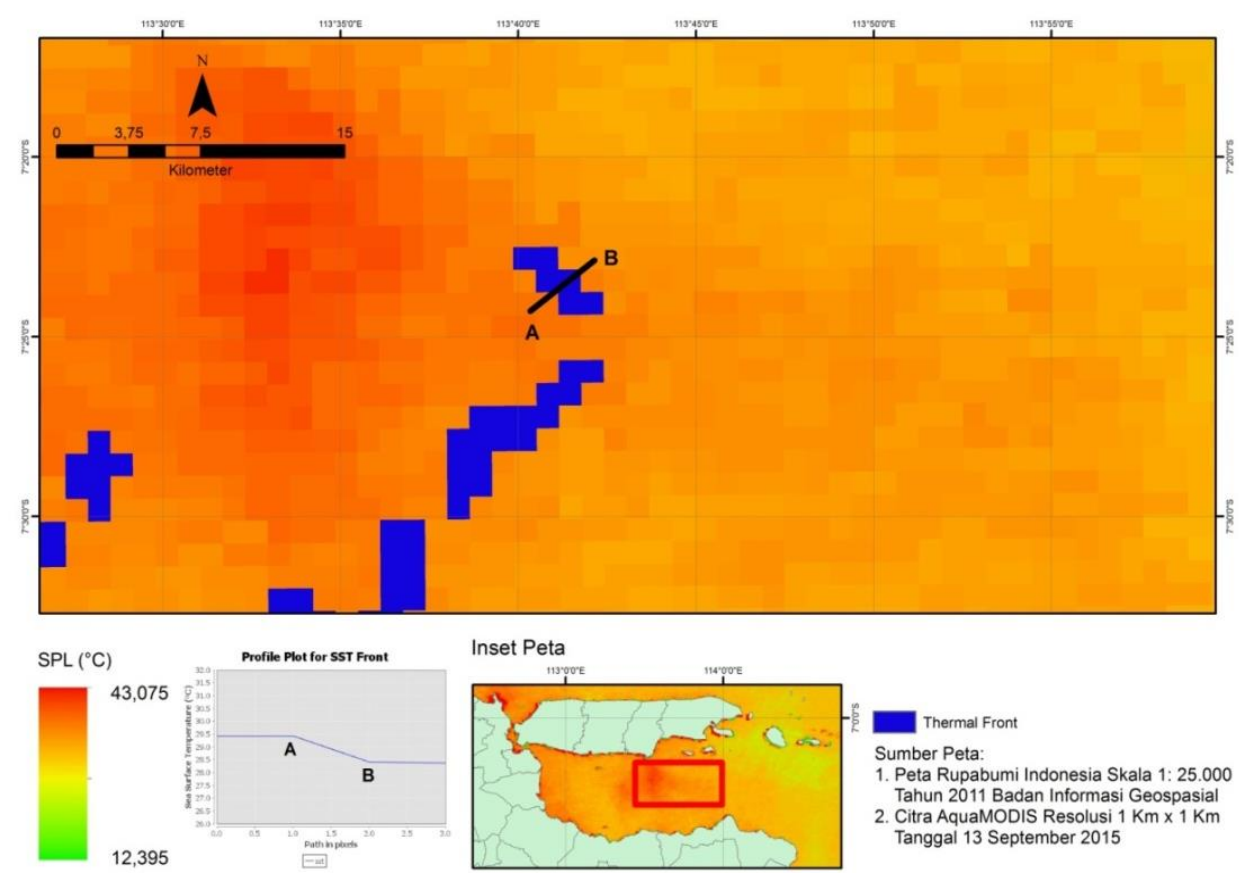

Gambar 1. Profile Plot Horizontal Suhu Permukaan Laut pada area yang terjadi Thermal Front di Perairan Selat Madura pada Tanggal 13 September 2015

Nilai $0,5^{\circ} \mathrm{C} /$ piksel dijadikan sebagai acuan dalam melakukan deteksi thermal front di Perairan Selat Madura sebagai nilai masukan threshold (batas tepi) dalam metode SIED (Jatisworo dan Murdimanto, 2013; Hamzah et al., 2014). Nilai gradien suhu ini memiliki arti bahwa dalam piksel yang saling bersebelahan memiliki perbedaan nilai suhu sebesar $0,5^{\circ} \mathrm{C}$. Piksel-piksel ini mewakili masa air, dimana piksel dengan nilai yang sama dianggap mewakili satu masa air (berdasarkan karakteristik suhunya). Gradien suhu yang terbentuk antara satu masa air dan masa air yang berada di sebelahnya dapat diasumsikan sebagai kekuatan front, hal ini dijelaskan oleh Simbolon et al (2013) yang membagi kekuatan front menjadi dua, yaitu front kuat dengan nilai gradien suhu $\geq 0,5^{\circ} \mathrm{C}$ dan front lemah dengan nilai gradien suhu berkisar antara $0,3^{\circ} \mathrm{C}-0,49^{\circ} \mathrm{C}$. 
Suhu permukaan laut di perairan Selat Madura memiliki perbedaan secara horizontal dan vertikal yang tidak terlalu besar, terlihat dari hasil pengukuran lapangan yang berkisar antara 26,5 $-30{ }^{\circ} \mathrm{C}$ (Hasyim, 2014). Hasil deteksi SPL dari citra satelit dapat menunjukkan karakteristik masa air, meskipun demikian diperlukan verifikasi data untuk memastikan kebenaran data dari citra satelit tersebut (Habibie dan Nuraini, 2014). Hasil verifikasi pada tanggal 25 Agustus 2017 ditunjukkan oleh Tabel 4 dengan nilai SPL hasil pengukuran lapangan pada sebelas stasiun berkisar antara $28,2-28,5^{\circ} \mathrm{C}$ dan deteksi nilai SPL oleh citra satelit sebesar $28,37^{\circ} \mathrm{C}$

Perbedaan nilai suhu yang signifikan antara satu piksel dengan piksel lainnya tidak selalu dapat dikatakan sebagai kejadian front. Hal ini dijelaskan oleh Cayula dan Cornillon (1992) bahwa dalam metode gradient magnitude, kecenderungan nilai gradien melintang suhu yang tinggi dapat menunjukkan adanya tepi (edge), namun metode ini dapat ditingkatkan dengan melihat gradien vektor dengan arah yang konstan untuk menunjukkan suatu masa air. Alasan tersebut yang membuat diperlukannya suatu batas untuk menentukan ada atau tidaknya tepi sebagai input dalam metode SIED, yaitu dengan menambahkan batas window size. Batas window size yang digunakan adalah sebesar $32 \times 32$ piksel, dengan memperhitungkan luas wilayah, resolusi data yang digunakan (resolusi citra AquaMODIS sebesar $1 \times 1 \mathrm{~km}$ ), serta gangguan (noise) yang ada pada citra (Cayula dan Cornillon, 1992; .Hamzah et al., 2014; Hanintyo et al., 2015)

Hasil deteksi thermal front dan model arus secara harian digunakan untuk mengetahui bagaimana thermal front dapat terbentuk di perairan Selat Madura. Kedua hasil ini dilakukan overlay untuk mengetahui bagaimana pengaruh dari arus terhadap pembentukan front. Peta overlay ini dibuat berdasarkan kejadian front secara harian, dengan data model yang digunakan menyesuaikan hasil deteksi front. Waktu yang digunakan adalah hari yang berada pada tiap musim selama 4 tahun.

Thermal front dapat terbentuk karena adanya pertemuan antara dua masa air dengan karakteristik suhu yang berbeda. Terjadinya front di permukaan dapat dipengaruhi oleh adanya pergerakan masa air secara horizontal yang ditunjukkan oleh gerakan arus permukaan laut (Gambar 2). Arus yang menggerakan masa air di Selat Madura sangat dipengaruhi oleh proses oseanografi yang terjadi di sebelah timur perairan Selat Madura, karena berdasarkan kondisi geografis Selat Madura yang relatif terbuka (bertemu dengan laut lepas) di sebelah timur, dan relatif tertutup di sebelah barat. Kondisi ini cenderung membuat proses oseanografi seperti arus di Selat Madura terjadi akibat adanya proses oseanografi lain di wilayah timur, atau perairan utara Bali dan Lombok. Pengaruh arus yang kuat dari wilayah timur Selat Madura dapat terlihat dari hasil model data arus dari setiap musim (Miller et al., 2013; Hasyim, 2014).

Kejadian front pada musim barat dapat dilihat pada Gambar 2a. Pola arus menunjukkan pergerakan masa air di lapisan permukaan. Hasil overlay antara data arus permukaan dan deteksi front secara harian menunjukkan bahwa pembentukan front di musim barat terjadi akibat adanya arus eddy (tanggal 5 Febuari 2014 dan 7 Januari 2016) dan pertemuan masa air yang masuk dan keluar dari perairan Selat Madura (tanggal 4 Febuari 2013 dan tanggal 28 Febuari 2015).

Fenomena eddy yang menyebabkan terjadinya front ditunjukkan dengan adanya bentuk arus melingkar di wilayah utara Kabupaten Probolinggo serta pertemuan antara masa air masuk dan keluar yang terjadi pada masa air dari wilayah timur bertemu dengan masa air di wilayah barat yang dipengaruhi oleh adanya masukan dari sungai (Isoda dan Saitoh, 1993; Miller et al., 2013; Hanintyo et al., 2015)

\section{Sebaran Thermal Front Musiman pada Tahun 2012-2016 di Selat Madura}

Kejadian thermal front yang dideteksi secara harian dapat digabungkan menjadi komposit secara statistik selama satu musim (3 bulan) untuk mengetahui lokasi dominan terjadinya front. Hasil penjumlahan statistik menunjukkan jumlah kejadian front dan menghitung seberapa banyak front terjadi di suatu wilayah yang ditunjukkan oleh warna pada keterangan peta. Raster hasil statistik tersebut disajikan tiap musim dalam satu tahun.

Thermal front di Perairan Selat Madura pada Musim Peralihan I dimulai pada bulan Maret Mei yang merupakan musim peralihan dari musim barat ke musim timur, sehingga proses oseanografi yang terjadi pada musim ini masih dipengaruhi oleh kedua musim tersebut. Pola arus pada tanggal 17 Maret 2013 menunjukkan adanya pergerakan arus dominan dari arah barat ke timur. Pergerakan arus ini terjadi karena tidak adanya arus yang bergerak dari arah timur 
Kabupaten Sumenep ke arah barat. Meskipun demikian, di wilayah timur Kabupaten Sidoarjo dan Kabupaten Pasuruan terjadi pertemuan arus yang menimbulkan front.

Kejadian front secara harian di musim timur hasil deteksi front pada tanggal 28 Juni 2013, 31 Juli 2015, dan 11 Juni 2016 menunjukkan bahwa arus yang berasal dari selatan Selat Bali memberikan pengaruh yang besar terhadap kejadian front, dimana terjadi pertemuan arus dari arah barat Selat Madura dan dari arah selatan Selat Bali yang kemudian membentuk front. Pola arus pada tanggal 17 Juli 2014 menunjukkan bahwa front terjadi karena adanya arus eddy di wilayah selatan Kabupaten Pamekasan. Thermal front pada Musim Peralihan II sebagian besar terjadi akibat adanya arus eddy, karena arus ini tidak hanya terjadi di wilayah barat Selat Madura, akan tetapi terjadi pula di wilayah timur Selat Madura seperti pada tanggal 4 September 2016, dimana arus eddy terjadi di bagian barat dan timur Selat Madura dan menimbulkan daerah front yang cukup panjang dari wilayah selatan Kabupaten Sumenep hingga bagian utara Kabupaten Situbondo.

Hasil perhitungan statistik piksel yang telah dilakukan, diperoleh data jumlah kejadian front dalam bentuk angka. Jumlah kejadian front dihitung berdasarkan piksel piksel dalam citra yang mengalami fenomena front dalam satu musim tiap tahun dari tahun 2012-2014. Data ini dapat dilihat pada Tabel 1 dan Gambar 4.

Berdasarkan hasil perhitungan statistik yang diperoleh, terlihat bahwa frekuensi kejadian front tertinggi terjadi pada Musim Peralihan II dengan rata-rata kejadian sebanyak 2375 kali, dan frekuensi kejadian front terendah terjadi pada Musim Barat dengan rata - rata kejadian sebanyak 446 kali. Hal ini disebabkan oleh adanya pengaruh dari adanya eddy current dengan intensitas tinggi pada musim Peralihan II, sedangkan pada Musim Barat, dimana masa air cenderung
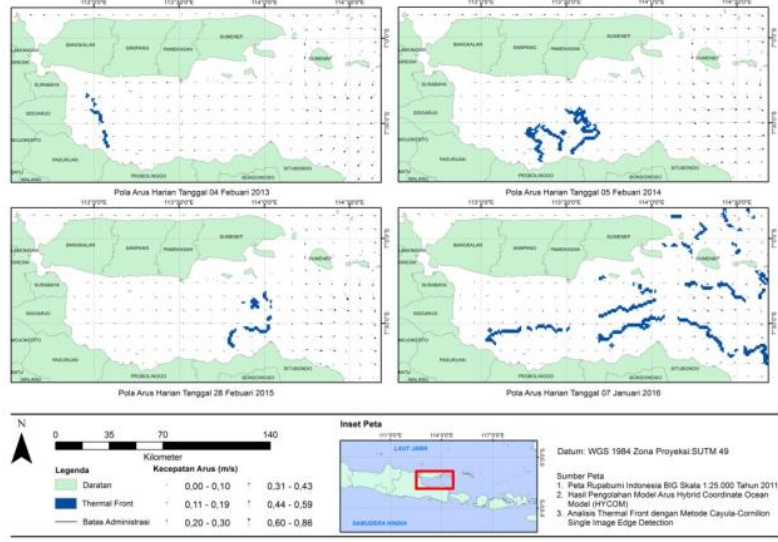

(a)
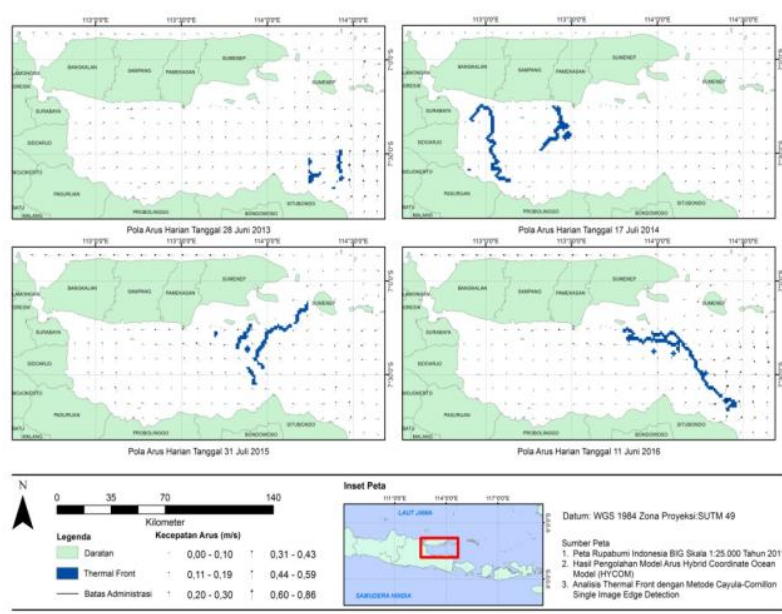

(c)
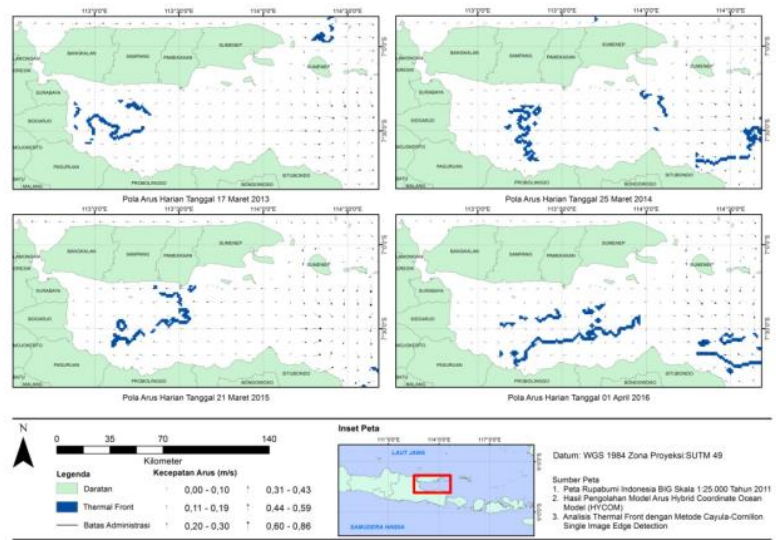

(b)
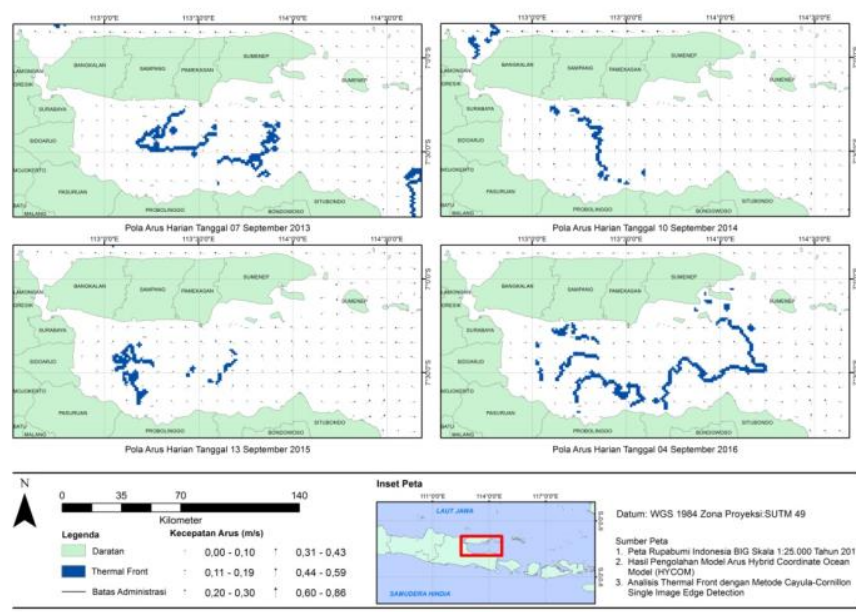

(d)

Gambar 2.Overlay Data Model Arus dan Thermal Front Harian pada (a) Musim Barat (b) Musim Peralihan I (c) Musim Timur (d) Musim Peralihan II 

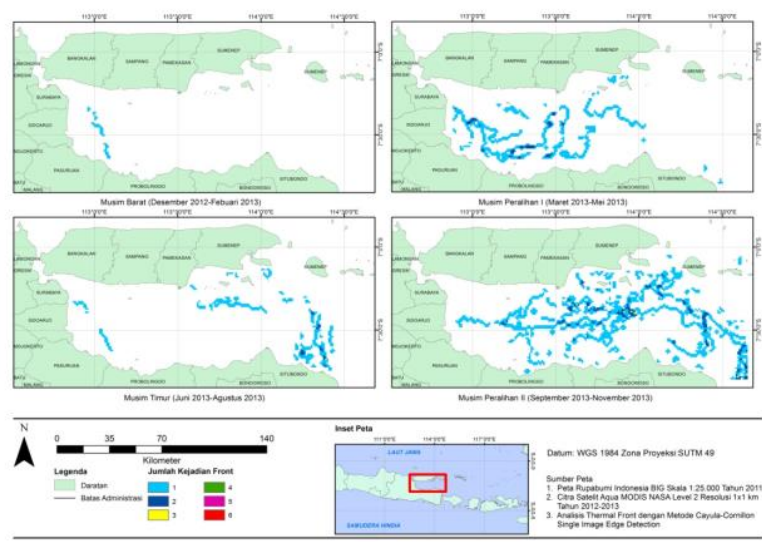

(a)
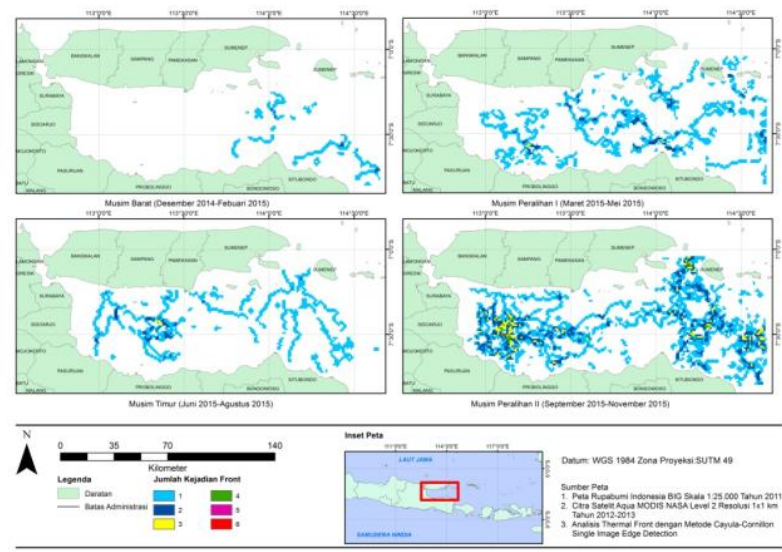

(c)
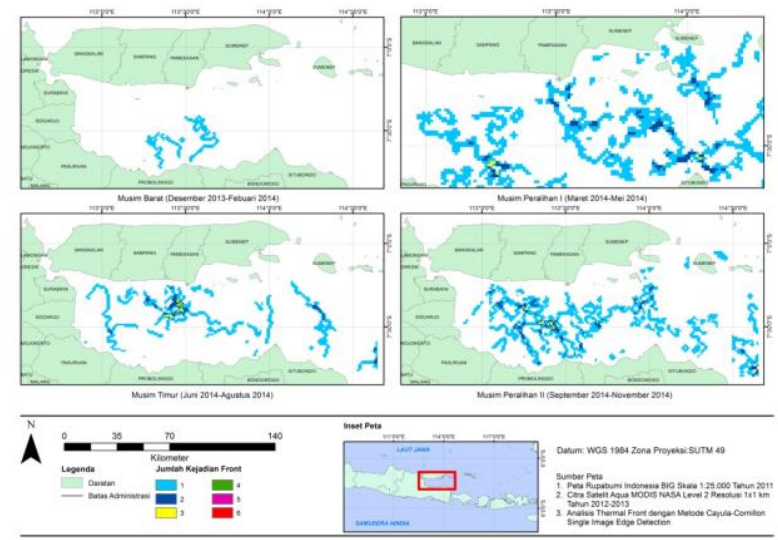

(b)

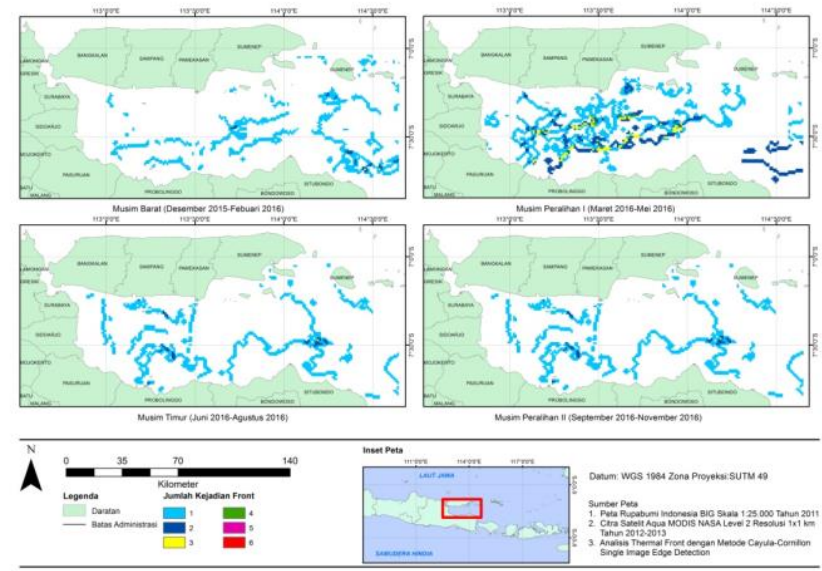

(d)

Gambar 3. Peta Sebaran Thermal Front pada (a) Tahun 2012-2013 (b) Tahun 2013-2014 (c) Tahun 2014-2015 (d) Tahun 2015-2016

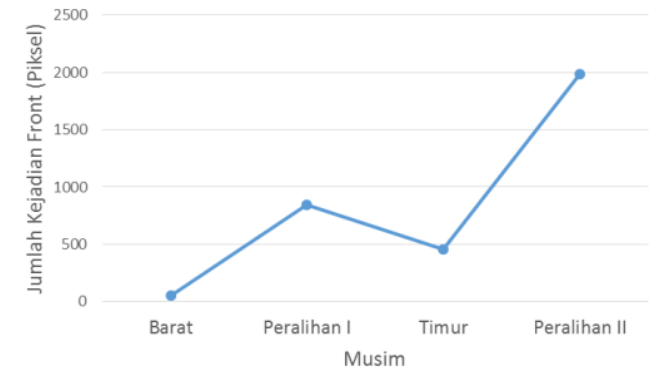

(a)

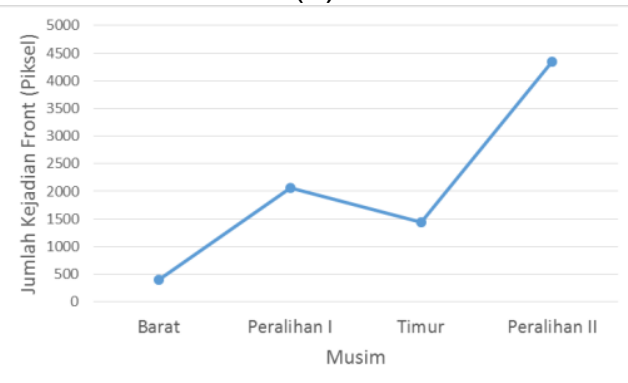

(c)

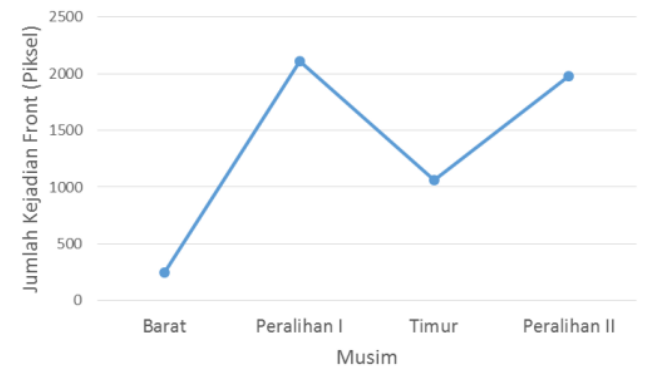

(b)

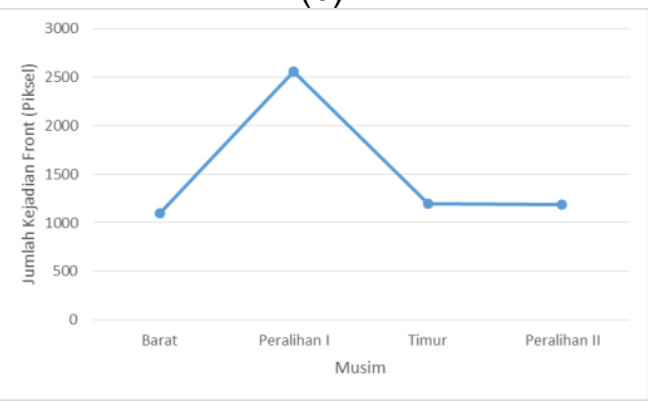

(d)

Gambar 4. Grafik Kejadian Thermal Front pada (a) Tahun 2012-2013 (b) Tahun 2013-2014 (c) Tahun 2014-2015 (d) Tahun 2015-2016 
Tabel 1. Jumlah Kejadian Front Musiman di Perairan Selat Madura (Berdasarkan Jumlah Piksel) pada Tahun 2012-2016

\begin{tabular}{rcccc}
\hline \multirow{2}{*}{ Tahun } & \multicolumn{4}{c}{ Musim } \\
\cline { 2 - 5 } & Barat & Peralihan I & Timur & Peralihan II \\
\hline $2012-2013$ & 48 & 847 & 459 & 1987 \\
$2013-2014$ & 245 & 2109 & 1058 & 1978 \\
$2014-2015$ & 396 & 2060 & 1438 & 4346 \\
$2015-2016$ & 1095 & 2556 & 1197 & 1191 \\
\hline Rerata & 446 & 1893 & 1038 & 2375 \\
\hline
\end{tabular}

bergerak ke arah timur menyebabkan kemungkinan untuk terjadi front menjadi lebih kecil. Sedangkan pada Musim Timur, dimana masa air cenderung bergerak dari wilayah timur Selat Madura menyebabkan adanya pertemuan masa air, karena wilayah barat Selat Madura merupakan perairan yang relatif tertutup. Pertemuan masa air ini kemudian menjadi front.

Musim Peralihan (Peralihan I dan II) memiliki frekuensi kejadian front yang lebih tinggi dibandingkan dengan Musim Timur dan Musim Barat. Hal ini disebabkan karena pada Musim Peralihan, proses oseanografi seperti eddy terjadi dengan intensitas yang lebih tinggi dibandingkan dengan musim lain. Fenomena thermal front yang terjadi di wilayah perairan Selat Madura akibat adanya arus eddy umumnya disebabkan oleh pergerakan arus yang bergerak berlawanan dengan arah jarum jam, dimana pergerakan ini di belahan bumi selatan (BBS) dapat mengakibatkan adanya fenomena downwelling karena adanya penumpukan massa di lapisan permukaan yang harus di alirkan ke lapisan dalam (Azis, 2006)

\section{KESIMPULAN}

Kesimpulan yang didapat dari penelitian ini adalah pembentukan thermal front di perairan Selat Madura dipengaruhi oleh beberapa faktor oseanografi seperti fenomena eddy current dan pertemuan arus. Sebaran thermal front berdasarkan musim, dengan kejadian tertinggi terjadi Musim Peralihan II (September - November) dengan rata-rata kejadian sebanyak 2375 kali dan paling sedikit terjadi pada Musim Barat (Desember - Febuari) dengan rata - rata kejadian sebanyak 446 kali. Fenomena eddy current mempengaruhi pembentukan front pada wilayah tengah hingga barat Selat Madura $\left(113^{\circ} \mathrm{BT}-114^{\circ} \mathrm{BT}\right)$ sedangkan fenomena pertemuan arus mempengaruhi pembentukan thermal front di wilayah timur Selat Madura yang berbatasan dengan Laut Bali (114 BT - $114^{\circ} 30^{\prime \prime}$ BT).

\section{UCAPAN TERIMAKASIH}

Artikel ini adalah bagian dari Skripsi yang berjudul "Variabilitas Thermal Front di Perairan Selat Madura, Jawa Timur" sebagai syarat memperoleh gelar Sarjana Strata Satu Program Studi Oseanografi Fakultas Perikanan dan IImu Kelautan, Universitas Diponegoro

\section{DAFTAR PUSTAKA}

Akhbar, A.I., Jaya, Y.V., \& Febrianto, T. 2018. Kajian Suhu Permukaan Laut Berdasarkan Data Citra Satelit NOAA-AVHRR dan Data Argo Float Di Perairan Selatan Jawa. Dinamika Maritim, 7(1):27-32.

Arief, M. 2004. Aplikasi Data Satelit Resolusi Rendah dan SIG untuk Analisa Distribusi Spasial Zona Potensi Penangkapan Ikan (ZPPI) di Selat Makassar. Lembaga Penerbangan dan Antariksa Nasional.

Azis, M.F., 2006. Gerak Air Di Laut. Oseana, Volume 31(4):9-21

Belkin, J.M. \& O'Reilly, J.E. 2009. An Algorithm For oceanic front Detection in Chlorophyl and SST Satellite Imagery, Journal of Marine System 78:319-328 
Cayula, J. \& Cornillon, P. 1992. Edge Detection Algorithm for SST Images. University of Rhode Island

Habibie, M.N. \& Nuraini, T.A. 2014. Karakteristik dan Tren Perubahan Suhu Permukaan Laut di Indonesia periode 1982-2009. Meteorologi dan Geofisika. 15(1): 37-49.

Hamzah, R., Prayogo, T. \& Harsanugraha, W.K.. 2014. Identifikasi Thermal Front dari Data Satelit Terra/Aqua Modis Menggunakan Metode Single Image Edge Detection (Sied) (Studi Kasus: Perairan Utara Dan Selatan Pulau Jawa). Pusat Pemanfaatan Penginderaan Jauh, Lembaga Penerbangan dan Antariksa Nasional

Hanintyo, R., Hadianti, S., Mahardhika, R.M.P., Aldino J.S., \& Islamy, F. 2015. Sebaran Musiman Kejadian Thermal Front Berdasarkan Citra AquaMODIS di WPP-RI 714, 715, dan 716. In Prossiding. Seminar Nasional Penginderaan Jauh.

Hasyim, B. 2014. Identifikasi Zona Potensi Penangkapan Ikan di Selat Madura Waktu Terjadi El Nino Berdasarkan Data Penginderaan Jauh. Pusat Pemanfaatan Penginderaan Jauh, Lembaga Penerbangan dan Antariksa Nasional

Isoda, Y. \& Saitoh, S.1993. The Northward Intruding Eddy along the East Coast of Korea. Jurnal of Oceanography, 49 (4): 443-458

Jatisworo, D. \& Murdimanto, A. 2013. Identifikasi Thermal Front di Selat Makassar dan Laut Banda. Balai Penelitian dan Observasi Laut. Prosiding Simposium Nasional Sainds Geoinformasi III.

Miller, P.I., Read, J.F. \& Dale, A.C. 2013. Thermal Front Variability along the North Atlantic Current Observed Using Microwave and Infrared Satellite Data. Elsevier, Deep Sea Research II

Mustasim, Mukti Zainuddin \& Safruddin. 2015. Thermal dan Klorofil A Font Hubungannya Dengan Hasil Tangkapan Ikan Cakalang Pada Musim Peralihan Barat-Timur di Perairan Seram. Jurnal IPTEKS Pemanfaatan Sumberdaya Perikanan, 2(4):294 - 304

Nammalwar, P., Sathees, S. \& Ramesh, R.. 2013. Applications of remote sensing in the validations of potential fishing zones (PFZ) along the coast of North Tamil Nadu India. Indian Journal Of Geo-Marine Sciences, 3:283-292.

Simbolon, D., Silvia \& Wahyuningrum, P.I. 2013. Pendugaan Thermal Front Dan Upwelling Sebagai Indikator Daerah Potensial Penangkapan Ikan Di Perairan Mentawai. Marine Fisheries, 4(1):85-95

Syaifullah, M.D. 2015. Suhu Permukaan Laut Perairan Indonesiadan Hubungannya Dengan Pemanasan Global. Segara, 11(1): 37-47

Valavanis, V.D., Katara, I., \& Palialexis, A. 2005. Marine GIS: Identification of Mesoscale Oceanic Thermal Fronts. International Journal of Geographical Information Science, 19(10):11311147 